\title{
Upaya Pencegahan Stunting Melalui Deteksi Dini dan Edukasi Orangtua Serta Kader Posyandu Di Dukuh Gupak Warak Desa Sendangsari Pajangan Bantul Yogyakarta
}

\author{
Lily Yulaikhah ${ }^{1}$, Ratih Kumorojati ${ }^{2}$, Dian Puspitasari ${ }^{3}$, Eniyati ${ }^{4}$ \\ ${ }^{1}$ Kebidanan (S1), Fakultas Kesehatan, Universitas Jenderal Achmad Yani, Yogyakarta, Indonesia \\ ${ }^{2,3}$ Pendidikan Profesi Bidan, Fakultas Kesehatan, Universitas Jenderal Achmad Yani, Yogyakarta, \\ Indonesia \\ ${ }^{4}$ Kebidanan (D3), Fakultas Kesehatan, Universitas Jenderal Achmad Yani, Yogyakarta, Indonesia \\ e-mail: ${ }^{1}$ athasafaraz@gmail.com, ${ }^{2}$ ratihkumorojati@gmail.com, ${ }^{3}$ dian.ayaniyka@gmail.com, \\ 4akhsaneni@gmail.com
}

\begin{abstract}
ABSTRAK Stunting merupakan masalah gizi kronis yang dapat mengganggu pertumbuhan anak karena menyebabkan tinggi badan anak tidak sesuai dengan umurnya atau lebih pendek. Permasalahan yang dapat ditimbulkan dari kondisi stunting adalah kemampuan kognitif yang lemah dan terhambatnya pertumbuhan psikomotorik, kesulitan dalam menguasai ilmu dan berprestasi dalam olahraga, rentan terkena penyakit degeneratif, dan kualitas sumber daya manusia yang rendah. Oleh karenanya untuk mencegah permasalahan yang mungkin dapat terjadi akibat kondisi stunting, perlu dilakukan penanganan secara menyeluruh dan terintegrasi terhadap semua aspek yang berhubungan dengan penyebab terjadinya stunting. Desa Sendangsari Kecamatan Pajangan Bantul merupakan salah satu lokus stunting nasional tahun 2019. Salah satu Dukuh di Desa Sendangsari yang cukup banyak masalah stunting adalah di Dukuh Gupak Warak. Salah satu upaya untuk mencegah terjadinya stunting adalah melalui deteksi dini dan edukasi terhadap orang tua dan kader posyandu, sehingga diharapkan angka stunting dapat diturunkan. Pengabdian ini menggunakan metode pendidikan kesehatan dan deteksi dini kelainan melalui pengukuran berat badan dan tinggi badan anak. Hasil kegiatan pengukuran tinggi badan anak ditemukan bahwa dari sejumlah 40 balita yang diukur terdapat 6 anak dengan gizi kurang, 5 anak pendek, 2 anak sangat pendek, 8 anak kurus, dan 3 anak sangat kurus. Cukup banyak orangtua yang belum mengetahui tentang stunting, dan pengukuran tinggi badan tidak rutin dilakukan pada saat kegiatan posyandu. Oleh karenanya disarankan kepada kader untuk melakukan pengukuran tinggi badan secara rutin dalam kegiatan posyandu setiap bulannya dan mencatat hasil pengukuran di dalam KMS. Untuk pihak Puskesmas maupun bidan desa juga diharapkan dapat memantau dan membina kader dan posyandu secara rutin serta menindaklanjuti temuan balita yang bermasalah.
\end{abstract}

KATA KUNCI stunting; balita; orangtua; kader

ABSTRACT Stunting is a chronic nutritional problem that can interfere with a child's growth because it causes the child's height to not match his age or be shorter. The problems that can be caused by stunting are weak cognitive abilities and inhibited psychomotor growth, difficulty in mastering knowledge and achievement in sports, susceptibility to degenerative diseases, and low quality of human resources. Therefore, to prevent problems that may occur due to stunting conditions, it is necessary to carry out comprehensive and integrated handling of all aspects related to the causes of stunting. Sendangsari Village, Pajangan Bantul District is one of the 2019 national stunting locus. One of the hamlets in

Lily Yulaikhah........................Upaya Pencegahan Stunting Melalui Deteksi Dini 
Sendangsari Village that has a lot of stunting problems is Dukuh Gupak Warak. One of the efforts to prevent stunting is through early detection and education of parents and posyandu volunteers, so it is hoped that the stunting rate can be reduced. This service uses health education methods and early detection of abnormalities through measuring the child's weight and height. The results of the measurement of children's height found that out of a total of 40 toddlers measured, 6 were malnourished, 5 were short, 2 were very short, 8 were thin, and 3 were very thin. Quite a number of parents do not know about stunting, and height measurements are not routinely carried out during posyandu activities. Therefore, it is advisable for posyandu volunteers to take regular height measurements in posyandu activities every month and record the measurement results in the KMS. It is also hoped that the Puskesmas and midwives can monitor and foster cadres and posyandu regularly and follow up on findings of children with problems.

KEYWORDS stunting, child, parents, posyandu volunteers

\section{Pendahuluan}

Pertumbuhan dan perkembangan anak merupakan hal yang harus diperhatikan sejak usia dini. Kegagalan pertumbuhan dan perkembangan akan berakibat terhadap kesejahteraaan anak. Salah satu gangguan dalam pertumbuhan anak yang saat ini sedang marak dibicarakan adalah stunting. Berdasarkan data Riset Kesehatan Dasar (Riskesdas) tahun 2018 Angka kejadian stunting di Indonesia sebesar 30,8\%. Hal ini masih jauh dari target WHO dimana angka stunting targetnya adalah $20 \%$ [1]. Stunting merupakan suatu kondisi dimana panjang atau tinggi badan kurang dibandingkan umurnya, dengan kata lain anak mengalami ganggunan pertumbuhan yang menyebabkan anak tidak bertambah tingginya sehingga menjadi pendek dibandingkan dengan usianya. Kondisi anak pendek merupakan tanda dari adanya masalah gizi kronis pada pertumbuhan anak [2].

Beberapa faktor yang menyebabkan terjadinya stunting diantaranya adalah kurangnya pengetahuan ibu mengenai kesehatan dan gizi pada masa sebelum dan masa kehamilan serta setelah melahirkan sehingga mengakibatkan kurang baiknya praktik pengasuhan anak, pelayanan kesehatan terutama ANC dan PNC sehingga akses untuk memperoleh pembelajaran dini yang berkualitas berkurang, masih kurangnya akses keluarga untuk memperoleh makanan bergizi yang disebabkan oleh masalah ekonomi yang rendah, kurangnya akses terhadap penggunaan air bersih dan sanitasi yang baik [3].

Untuk mencegah terjadinya stunting diperlukan penanganan yang komprehensif terhadap semua pihak yang terkait dengan pertumbuhan anak yaitu orang tua terutama ibu, keluarga, lingkungan serta tenaga kesehatan dalam melakukan pemantauan pertumbuhan anak. Berbagai upaya yang dilakukan oleh pemerintah dalam rangka menanggulangi terjadinya stunting terdapat lima pilar penanganan stunting yaitu 1) komitmen dan visi pimpinan tertinggi Negara, 2) kampanye nasional berfokus pada pemahaman, perubahan perilaku, komitmen politik dan akuntabilitas, 3) konvergensi, koordinasi, dan konsolidasi program nasional, daerah, dan masyarakat, 4) mendorong kebijakan "nutritional food security", 5) pemantauan dan evaluasi. Kelima pilar tersebut dilakukan secara terintegrasi dan saling terkait antar komponen [4].

Pada tahun 2019, Yogyakarta merupakan salah satu daerah yang menjadi lokus stunting di tingkat nasional, salah satu wilayahnya adalah Kabupaten Bantul dengan jumlah anak stunting pada tahun 2018 sebanyak 770 Balita. Sejumlah balita tersebut tersebar ke dalam sepuluh desa yang dijadikan lokus stunting di wilayah 
Kabupaten Bantul yaitu Desa Triwidadi, Sendangsari, Trimulyo, Canden, Patalan, Timbulharjo, Triwidadi, Jatimulyo, Terong, Argodadi. Desa Sendangsari merupakan desa dengan jumlah stunting terbanyak ketiga dari sepuluh desa tersebut yaitu sejumlah 96 balita [5]. Dari sejumlah dukuh yang ada di Desa Sendangsari, terdapat salah satu dukuh yang cukup banyak ditemukan kasus stunting yaitu Dukuh Gupak Warak, sehingga pelaksanaan pengabdian ini difokuskan di Dukuh Gupak Warak, Desa Sendangsari, Kecamatan Pajangan, Kabupaten Bantul Yogyakarta. Berdasarkan wawancara dengan kader posyandu, belum pernah dilakukan penyuluhan secara spesifik serta pelatihan mengenai deteksi stunting pada anak balita.

Oleh karenanya, sebagai salah satu upaya untuk mencegah terjadinya stunting di Dukuh Gupak Warak Desa Sendangsari dilakukan kegiatan pengabdian kepada masyarakat melalui deteksi dini dan edukasi terhadap orang tua balita serta kader posyandu, sehingga diharapkan stunting dapat dicegah dan diatasi sedini mungkin. Kegiatan pengabdian kepada masyarakat ini bertujuan untuk mendeteksi secara dini stunting pada anak, meningkatkan pemahaman orang tua tentang pencegahan stunting dan meningkatkan kemampuan kader dalam melakukan deteksi dini stunting pada anak balita.

\section{Metode}

Kegiatan ini dilaksanakan di Posyandu Kenanga Dukuh Gupak Warak Desa Sendangsari pada bulan Oktober 2019. Sasaran dalam kegiatan ini meliputi balita sebanyak 54 anak yang ada di wilayah Posyandu Kenanga Dukuh Gupak Warak, orangtua 54 orang dan kader posyandu 8 orang, namun dalam pelaksanannya yang datang ke Posyandu adalah 47 balita dan orangtua. Dalam upaya mengatasi stunting di Dukuh Gupak Warak dilakukan dengan melibatkan balita, orangtua dan kader posyandu melalui pendekatan deteksi dini kelainan dan pendidikan kesehatan. Dalam mendeteksi adanya kelainan, metode yang digunakan dalam melakukan deteksi dini kelainan yaitu 1) Mengidentifikasi kondisi anak melalui anamnesa kepada orangtua, 2) Melakukan pengukuran tinggi badan dan berat badan anak balita, 3) Menginterpretasikan hasil pengukuran tinggi badan dan berat badan anak balita ke dalam curva WHO yang terdiri dari berat badan berdasarkan jenis kelamin, umur dan tinggi badan kemudian hasilnya diinterpretasikan ke dalam Tabel 1 Zskor menurut WHO sebagai berikut:

Tabel 1. Z-skor menurut WHO

\begin{tabular}{|l|l|l|}
\hline \multicolumn{1}{|c|}{ Z-skor } & \multicolumn{1}{|c|}{ Panjang/Tinggi terhadap } & \multicolumn{1}{c|}{ Keterangan } \\
\hline Di atas 3 & Tinggi & $\begin{array}{l}\text { Anak dalam kelompok ini berperawakan tubuh } \\
\text { tinggi. Hal ini tidak masih normal. Singkirkan } \\
\text { kelainan hormonal sebagai penyebab perawakan } \\
\text { tinggi. }\end{array}$ \\
\hline Di atas 2 & Normal & \\
\hline Di atas 1 & Normal & \\
\hline 0 (median) & Normal & Hal ini merujuk pada gizi sangat kurang \\
\hline Dibawah -1 & Normal & \\
\hline Dibawah -2 & Pendek & \\
\hline Dibawah -3 & Sangat Pendek/Kerdil & \\
\hline
\end{tabular}

Keterangan: Garis 0 pada kurva pertumbuhan WHO menggambarkan median, atau rata-rata; Garis yang lain dinamakan garis z-score; Pada kurva pertumbuhan WHO garis ini diberi angka positif (1, $2,3)$ atau negatif $(-1,-2,-3)$; Titik temu yang berada jauh dari garis median menggambarkan masalah pertumbuhan; Titik temu yang berada antara garis z-score -2 dan -3 diartikan di bawah -2; Titik temu yang berada antara garis z-score 2 dan 3 diartikan di atas 2 . 
4) Menyampaikan hasil pengukuran balita kepada orangtua, 5) Memberikan edukasi (pendidikan kesehatan) kepada orangtua tentang stunting mulai dari pengertian, penyebab, tanda, cara mencegah dan cara mengatasi serta memberikan leaflet tentang stunting, 6) Memberikan edukasi kepada kader posyandu mengenai stunting dengan memberikan pelatihan tentang cara pengukuran tinggi badan dan berat badan, memasukan hasil pengukuran ke dalam curva, menginterpretasikan hasil pengukuran dan tindak lanjut hasil pengukuran melalui pelaporan ke pihak Puskesmas.

\section{Hasil dan Pembahasan}

Dukuh Gupak Warak merupakan salah satu dukuh di Desa Sendangsari Kecamatan Pajangan Kabupaten Bantul Yogyakarta. Posyandu di Dukuh Gupak Warak bernama Posyandu Kenanga. Kegiatan posyandu di Dukuh ini dilaksanakan rutin setiap bulan sekali. Kader yang tercatat ada 8 orang, namun yang hadir saat pelaksanaan posyandu tidak menentu, karena ada beberapa kader yang bekerja. Seluruh kader sudah mengikuti pelatihan kader posyandu. Pada saat pelaksanaan kegiatan ini ada 5 orang kader yang hadir. Dalam pelaksanaan posyandu tidak ada pembagian tugas antar kader sehingga pelaksanaan sistem lima meja belum berjalan secara efektif. Selama ini kegiatan posyandu hanya mengukur berat badan dan pemberian makanan tambahan (PMT) yang biayanya bersumber dari masyarakat. Pengukuran tinggi badan di posyandu pernah dilakukan tetapi tidak rutin dan kadang dilakukan tiga bulan sekali pada saat ada petugas dari puskesmas, sehingga hasil pengukuran tinggi badan langsung dibawa ke puskesmas dan tidak ada dokumen di posyandu tentang hasil pengukuran tinggi badan. Peralatan yang ada di posyandu berupa timbangan berat badan dan pengukur tinggi badan yang baru dibagi dari puskesmas, namun belum pernah dipakai. Selama ini jika ada pengukuran tinggi badan dilakukan dengan menggunakan pengukur baju (metlin). Jumlah balita yang tercatat di posyandu kenanga sejumlah 54 anak. Di dalam KMS yang dicatat hanya hasil pengukuran berat badan, sehingga grafik pengukuran tinggi badan belum dapat dilakukan pemantauan melalui KMS. Berikut ini adalah hasil kegiatan yang dilaksanakan:

a. Data balita berdasarkan jenis kelamin dan umur

Jumlah balita yang datang ke posyandu seluruhnya ada 47 anak, namun terdapat 5 anak datanya tidak lengkap dan 2 anak usianya di atas 5 tahun, sehingga jumlah balita yang diperhitungkan dalam tabel berikut jumlahnya adalah 40 anak.

Tabel 2. Data balita berdasarkan kelamin dan umur

\begin{tabular}{clccc}
\hline \multirow{2}{*}{ No } & \multicolumn{1}{c}{ Umur } & \multicolumn{2}{c}{ Jenis Kelamin } & \multirow{2}{*}{ Jumlah } \\
\cline { 3 - 4 } & & Laki-laki & Perempuan & \\
\hline 1 & Bayi (0-12 bulan) & 6 & 10 & $16(40 \%)$ \\
\hline 2 & Batita (13-26 bulan) & 8 & 4 & $12(30 \%)$ \\
\hline 3 & Balita (37-60 bulan) & 9 & 3 & $12(30 \%)$ \\
\hline \multicolumn{2}{l}{ Jumlah } & $23(57,5 \%)$ & $17(42,5 \%)$ & $40(100 \%)$ \\
\hline
\end{tabular}

Berdasarkan Tabel 2. diketahui bahwa sebagian besar anak berjenis kelamin laki-laki $(57,5 \%)$ dan berada pada rentang usia $0-12$ bulan (40\%).

b. Data balita berdasarkan berat badan berdasarkan umur $(\mathrm{BB} / \mathrm{U})$ dan jenis kelamin 
Tabel 3. Data balita berdasarkan berat badan berdasarkan umur (BB/U) dan jenis kelamin

\begin{tabular}{|c|c|c|c|c|}
\hline \multirow{2}{*}{ No } & \multirow{2}{*}{ Umur } & \multicolumn{2}{|c|}{$\mathrm{BB} / \mathrm{U}$} & \multirow{2}{*}{ Jumlah } \\
\hline & & Normal & Gizi Kurang & \\
\hline 1 & Bayi (0-12 bulan) & 15 & 1 & 16 \\
\hline 2 & Batita (13-36 bulan) & 10 & 2 & 12 \\
\hline 3 & Balita (37-60 bulan) & 9 & 3 & 12 \\
\hline & Jumlah & $34(85 \%)$ & $6(15 \%)$ & $40(100 \%)$ \\
\hline
\end{tabular}

Berdasarkan penghitungan berat badan berdasarkan umur $(\mathrm{BB} / \mathrm{U})$ ditemukan sejumlah $6(15 \%)$ anak mengalami gizi kurang.

Tabel 3. Data balita berdasarkan berat badan berdasarkan umur $(\mathrm{BB} / \mathrm{U})$ dan jenis kelamin

\begin{tabular}{ccccc}
\hline \multirow{2}{*}{ No } & \multirow{2}{*}{ Jenis Kelamin } & \multicolumn{2}{c}{ BB/U } & \multirow{2}{*}{ Jumlah } \\
\cline { 3 - 4 } & & Normal & Gizi Kurang & \\
\hline 1 & Laki-laki & 18 & 5 & 23 \\
\hline 2 & Perempuan & 16 & 1 & 17 \\
\hline & Jumlah & 34 & 6 & 40 \\
\hline
\end{tabular}

Sedangkan dilihat berdasarkan jenis kelamin, sejumlah 6 anak yang mengalami gizi kurang sebagian besar berjenis kelamin laki-laki sebanyak 5 anak $(83,3 \%)$.

c. Data balita berdasarkan tinggi/panjang badan berdasarkan umur (PB/U) dan jenis kelamin

Tabel 4. Data balita berdasarkan tinggi/panjang badan berdasarkan umur (PB/U) dan jenis kelamin

\begin{tabular}{llcccc}
\hline \multirow{2}{*}{ No } & \multirow{2}{*}{ Umur } & \multicolumn{3}{c}{ PB/U } & \multirow{2}{*}{ Jumlah } \\
\cline { 3 - 5 } & Normal & Pendek & $\begin{array}{c}\text { Sangat } \\
\text { Pendek }\end{array}$ & \\
\hline 1 & Bayi (0-12 bulan) & 15 & 1 & 0 & 16 \\
\hline 2 & Batita (13-36 bulan) & 9 & 2 & 1 & 12 \\
\hline 3 & Balita (37-60 bulan) & 9 & 2 & 1 & 12 \\
\hline & Jumlah & 33 & 5 & 2 & 40 \\
\hline
\end{tabular}

Berdasarkan pengukuran panjang/tinggi badan berdasarkan umur ditemukan terdapat 5 anak yang pendek $(12,5 \%)$ dan 2 anak sangat pendek $(5 \%)$.

Tabel 5. Data balita berdasarkan tinggi/panjang badan berdasarkan umur (PB/U) dan jenis kelamin

\begin{tabular}{|c|c|c|c|c|c|}
\hline \multirow{2}{*}{ No } & \multirow{2}{*}{ Jenis Kelamin } & \multicolumn{3}{|c|}{$\mathrm{PB} / \mathrm{U}$} & \multirow{2}{*}{ Jumlah } \\
\hline & & Normal & Pendek & Sangat Pendek & \\
\hline 1 & Laki-laki & 18 & 3 & 2 & 23 \\
\hline \multirow[t]{2}{*}{2} & Perempuan & 15 & 2 & 0 & 17 \\
\hline & Jumlah & 33 & 5 & 2 & 40 \\
\hline
\end{tabular}

Dari sejumlah 7 anak yang berada dalam kategori pendek dan sangat pendek, sebagian besar berjenis kelamin laki-laki sejumlah 5 anak $(71,4 \%) .1$

d. Data balita berdasarkan berat badan dan panjang/tinggi badan (BB/PB)

Tabel 6. Data balita berdasarkan berat badan dan panjang/tinggi badan (BB/PB) 


\begin{tabular}{llcccc}
\hline \multirow{2}{*}{ No } & \multirow{2}{*}{ Umur } & Normal & Kurus & $\begin{array}{c}\text { Sangat } \\
\text { Kurus }\end{array}$ & Jumlah \\
\cline { 3 - 5 } & & 15 & 0 & 1 & 16 \\
\hline 1 & Bayi (0-12 bulan) & 7 & 4 & 1 & 12 \\
\hline 2 & Batita (13-36 bulan) & 7 & 4 & 1 & 12 \\
\hline 3 & Balita (37-60 bulan) & $29(72,5 \%)$ & $8(20 \%)$ & $3(7,5 \%)$ & $40(100 \%)$ \\
\hline \multicolumn{2}{l}{ Jumlah } &
\end{tabular}

Berdasarkan pengukuran berat badan berdasarkan panjang/tinggi badan ditemukan bahwa terdapat 8 anak yang kurus (20\%) dan 3 anak sangat kurus $(7,5 \%)$.

Tabel 7. Data balita berdasarkan berat badan dan panjang/tinggi badan (BB/PB)

\begin{tabular}{|c|c|c|c|c|c|}
\hline \multirow{2}{*}{ No } & \multirow{2}{*}{ Jenis Kelamin } & \multicolumn{3}{|c|}{$\mathrm{BB} / \mathrm{PB}$} & \multirow{2}{*}{ Jumlah } \\
\hline & & Normal & Kurus & Sangat Kurus & \\
\hline 1 & Laki-laki & 15 & 6 & 2 & 23 \\
\hline 2 & Perempuan & 14 & 2 & 1 & 17 \\
\hline & Jumlah & 29 & 8 & 3 & 40 \\
\hline
\end{tabular}

Dari 11 anak yang berada dalam kategori kurus dan sangat kurus, sejumlah 8 anak $(72,7 \%)$ berjenis kelamin laki-laki dan 3 anak $(27,3 \%)$ berjenis kelamin perempuan.

e. Data balita berdasarkan berat badan, panjang/tinggi badan, dan umur

Tabel 8. Data balita berdasarkan berat badan, panjang/tinggi badan, dan umur

\begin{tabular}{cccccc}
\hline \multirow{2}{*}{ No } & \multirow{2}{*}{ BB/U } & \multicolumn{3}{c}{$\mathbf{P B / U}$} & \multirow{2}{*}{ Jumlah } \\
\cline { 2 - 5 } & & Normal & Pendek & Sangat Pendek & \\
\hline 1 & Normal & 30 & 4 & 0 & 34 \\
\hline 2 & Gizi Kurang & 3 & 1 & 2 & 6 \\
\hline & Jumlah & 33 & 5 & 2 & 40 \\
\hline
\end{tabular}

Berdasarkan tabel 8. diketahui bahwa terdapat 7 anak yang berada dalam kategori pendek dan sangat pendek, dan dari sejumlah 7 anak tersebut 4 anak gizinya normal dan 3 anak gizi kurang.

Tabel 9. Data balita berdasarkan berat badan, panjang/tinggi badan, dan umur

\begin{tabular}{|c|c|c|c|c|c|}
\hline \multirow{2}{*}{ No } & \multirow{2}{*}{$\mathrm{BB} / \mathrm{U}$} & \multicolumn{3}{|c|}{ BB/PB } & \multirow{2}{*}{ Jumlah } \\
\hline & & Normal & Kurus & Sangat Kurus & \\
\hline 1 & Normal & 27 & 7 & 0 & 34 \\
\hline \multirow[t]{2}{*}{2} & Gizi Kurang & 2 & 1 & 3 & 6 \\
\hline & Jumlah & 29 & 8 & 3 & 40 \\
\hline
\end{tabular}

Berdasarkan Tabel 9. diketahui bahwa terdapat 11 anak yang berada dalam kategori kurus dan sangat kurus, dan dari sejumlah 11 anak tersebut 7 anak gizinya normal dan 4 anak gizi kurang.

Tabel 10. Data balita berdasarkan berat badan, panjang/tinggi badan, dan umur

\begin{tabular}{|c|c|c|c|c|c|}
\hline \multirow{2}{*}{ No } & \multirow{2}{*}{$\mathbf{P B} / \mathrm{U}$} & \multicolumn{3}{|c|}{$\mathrm{BB} / \mathrm{PB}$} & \multirow{2}{*}{ Jumlah } \\
\hline & & Normal & Kurus & Sangat Kurus & \\
\hline 1 & Normal & 23 & 7 & 3 & 33 \\
\hline 2 & Pendek & 5 & 0 & 0 & 5 \\
\hline 3 & Sangat Pendek & 1 & 1 & 0 & 2 \\
\hline & Jumlah & 29 & 8 & 3 & 40 \\
\hline
\end{tabular}


Berdasarkan tabel 10 diketahui bahwa terdapat 7 anak yang berada dalam kategori pendek dan sangat pendek, dan dari sejumlah 7 anak tersebut 6 anak normal dan 1 anak kurus. Namun dapat dilihat juga bahwa dari sejumlah anak yang tingginya normal (33 anak) ternyata terdapat 7 anak kategorinya kurus dan 3 anak sangat kurus.

\section{Kegiatan edukasi/penyuluhan terhadap orang tua}

Kegiatan penyuluhan terhadap orang tua balita terlaksana dengan cukup baik dengan memberikan penyuluhan berdasarkan kelompok kedatangan. Namun ada beberapa kendala yang dialami di antaranya yaitu:

a. Tidak semua orangtua kandung datang, ada yang dititipkan ke nenek atau saudaranya.

b. Datangnya orang tua tidak bersamaan sehingga kegiatan penyuluhan cukup memakan waktu dan tenaga.

c. Tempat yang kurang kondusif mempengaruhi pelaksanaan penyuluhan.

Hasil penyuluhan sebagian besar orangtua atau pendamping anak pada awalnya cukup banyak yang belum mengetahui tentang stunting, karena mereka menganggap bahwa pertumbuhan anak cukup dilihat dari berat badan saja. Setelah dilakukan penyuluhan sebagian besar orangtua/pendamping mengetahui bahwa gizi juga dapat mempengaruhi tinggi badan anak, dan selama ini mereka tidak memantau tinggi badan anak, sehingga diarahkan untuk pemantuan di posyandu sebaiknya minta diukur juga tinggi badannya. Pengukuran hasil penyuluhan dilakukan langsung secara lisan, dengan hasil sebagian besar cukup mengerti tentang stunting. Pemahaman orang tua juga dilihat dari antusiasme bertanya saat diberikan penyuluhan. Hal ini dikarenakan adanya beberapa kendala yaitu orang tua terburu-buru pulang dan tidak datang secara bersamaan, sehingga pelaksanaan penyuluhan dilakukan secara bertahap. Secara umum hasil penyuluhan cukup dipahami oleh para orang tua, meskipun evaluasi dilaksanakan secara kualitatif. Namun demikian ke depannya perlu dilakukan pengukuran secara kuantitatif dalam mengevaluasi hasil penyuluhan.

\section{Kegiatan edukasi kader}

Kegiatan edukasi terhadap kader dilakukan setelah selesai kegiatan posyandu dan seluruh balita dan orangtua sudah pulang. Dalam kegiatan edukasi terhadap kader disampaikan mengenai cara memantau panjang/tinggi badan anak dan mendeteksi kondisi stunting. Hasil evaluasi terhadap kader posyandu selama ini tidak rutin mengukur tinggi badan saat posyandu dikarenakan keterbatasan jumlah kader, dan pengukurannya menggunakan meteran kain (metlin). Setelah diberikan edukasi tentang pentingnya pemantauan tinggi badan untuk mendeteksi stunting, kader mengetahui dan menyadari pentingnya mengukur tinggi badan, dan akan diusahakan untuk mengukur tinggi badan anak secara rutin pada saat kegiatan posyandu berikutnya serta akan memperbaiki dokumentasi untuk pencatatan dan pelaporan kegiatan posyandu termasuk hasil pengukuran tinggi badan di dalam KMS.

\section{Kesimpulan}

Berdasarkan kegiatan yang telah dilaksanakan dapat disimpulkan hal-hal sebagai berikut: 1) Hasil pengukuran Berat badan berdasarkan umur (BB/U) ditemukan dari 40 anak terdapat 6 anak yang mengalami gizi kurang; 2) Hasil pengukuran panjang/tinggi badan berdasarkan umur (PB/U) ditemukan bahwa dari 40 anak 
terdapat 5 anak pendek dan 2 anak sangat pendek; 3) Hasil pengukuran berat badan berdasarkan panjang badan (BB/PB) ditemukan bahwa dari 40 anak terdapat 8 anak kurus dan 3 anak sangat kurus; 4) Hasil penghitungan berat badan berdasarkan umur $(\mathrm{BB} / \mathrm{U})$ dengan panjang badan berdasarkan umur $(\mathrm{PB} / \mathrm{U})$ ditemukan bahwa dari 7 anak yang berada dalam kategori pendek dan sangat pendek terdapat 3 anak yang gizinya kurang dan 4 anak gizinya normal; 5) Hasil penyuluhan terhadap orangtua sebagian besar orang tua cukup mengetahui tentang stunting; 6) Hasil edukasi terhadap kader tentang pentingnya deteksi dini stunting, seluruh kader menyadari pentingnya pengukuran tinggi badan anak untuk mendeteksi adanya stunting pada anak..

\section{Ucapan terima kasih}

Dalam kegiatan Pengabdian kepada masyarakat ini telah banyak pihak yang membantu dalam pelaksanaannya. Untuk itu kami sampaikan terima kasih kepada pihak-pihak yang telah membantu terlaksananya kegiatan ini dengan lancar di antaranya kepada Yang Terhormat:

a. Rektor Universitas Jenderal Achmad Yani Yogyakarta

b. Dekan Fakultas Kesehatan Unjani Yogyakarta

c. Ketua LPPM Unjani Yogyakarta dan PPPM Fakultas Kesehatan

d. Kepala Dinas Kesehatan Kabupaten

e. Kepala Puskesmas Pajangan Bantul

f. Bidan Desa Sendangsari

g. Kepala Desa Sendangsari

h. Pak Dukuh Gupak Warak

i. Kader Posyandu Kenanga Dukuh Gupak Warak

j. Seluruh masyarakat Dukuh Gupak Warak khususnya para orangtua balita.

\section{Daftar pustaka}

[1] Kemenkes, 2018. Hasil Utama Riskesdas 2018. Jakarta.

[2] Pusat Data dan Informasi, 2018. Buletin Jendela Data dan Informasi Kesehatan Semester I 2018. Jakarta. ISSN 2088270 X.

[3] TNP2K, 2017. 100 Kabupaten/Kota Prioritas untuk Intervensi Anak Kerdil (Stunting). Jakarta.

[4] Direktur Gizi dan Masyarakat, 2019. Kebijakan dan Strategi Penanggulangan Stunting di Indonesia. Jakarta.

[5] Dinkes Bantul, 2019. Lokus Stunting Kabupaten Bantul. Yogyakarta. 